\title{
Measurement of Thermal Diffusivity and Conductivity for Metal-hydrogen
}

\author{
Masanori MONDE*2 and Yuhichi MITSUTAKE \\ ${ }^{* 2}$ Department of Mechanical Engineering, Saga University, \\ 1 Honjo, Saga-shi, Saga, 840-8502 Japan
}

\begin{abstract}
A new composition material for metal-hydrogen, which can store hydrogen, has been developed to increase amount of hydrogen absorption. Thermal diffusivity and conductivity for the new composition material are required to design a storage tank with the metal-hydrogen. For the metalhydrogen called as $\mathrm{AB}_{5}$, themal diffusivity and conductivity are measured by using a method newly developed based on an inverse solution for one dimensional heat conduction. It reveals that the thermal diffusivity, a, is almost constant value of $4.0 \times 10^{-7} \mathrm{~m} / \mathrm{s}^{2}$ in a range of 10 to $30^{\circ} \mathrm{C}$ and of 0.148 to $0.502 \mathrm{MPa}$, while the thermal conductivity linearly increases from 1.0 to $3.0 \mathrm{~W} /(\mathrm{mK})$ for the different temperature with the pressure and the composition rate.
\end{abstract}

Key Words : Metal-hydrogen, Measurement of Thermal Properties, Thermal Conductivity, Thermal Diffusivity, Inverse Solution

\section{1. はじめに}

水素は, 高いエクセルギー効率をもっていることか ら2 次エネルギーとして最近注目されているのみなら ず, 燃料電池の普及につれて広く利用されることが期 待される. 特に, 燃料電池車の開発は, 都市の大気環 境保全にとって緊急課題となっている. 水素を基盤と した社会インフラのためには, 水素を貯蔵するシステ 厶の開発も重要な課題となる。この水素を貯蔵する方 法の 1 つとして, 水素吸蔵合金 $(\mathrm{MH})$ を利用した貯蔵 方法が提案されている. しかし，この合金による水素 の吸収あるいは放出は水素と合金との熱化学反応とな る. そして, この熱化学反応で発生する熱の輸送が反 応速度を支配（伝熱律則）することになる. 従って, そこでの熱移動量を推定するためには, 水素吸蔵時の 合金の温度伝導率と熱伝導率が必要となる。 $\mathrm{AB}_{5}$ 系 水素吸蔵合金は最近開発された合金で, その熱物性が データベース化されていないこと, および $\mathrm{AB}_{5}$ 系を 用いた水素貯蔵タンクの設計をする必要性から $\mathrm{AB}_{5}$ 系水素吸蔵合金を測定対象として選定し, 新しい測定 法(1)に基づいて測定装置を設計製作した，なお，本装 置で測定される温度伝導率と熱伝導率は, 数十ミクロ

* 原稿受付 2004 年 1 月 15 日.

*1 正員, 佐賀大学理工学部 (必840-8502 佐賀市本庄町 1).

E-mail : monde@me.saga-u.ac.jp
ン程度の粒子状の水素吸蔵合金が, ある水素原子数比 で活性化された状態で測定されている。 そして, 測定 された温度伝導率と熱伝導率は, 多孔質に対する值と なることからみかけの值となる.

本研究では, 門出ら(1)によって提案された測定法を 利用して, 想定される水素貯蔵タンクの使用範囲 $\left(50^{\circ} \mathrm{C}\right.$ 以下)での見かけの温度伝導率と見かけの熱伝導 率について測定した結果について報告する.

\section{主 要 記 号}

$a \quad:$ みかけの温度伝導率
$b_{\mathrm{j}, \mathrm{n}, \mathrm{n}}:$ 式(6)の係数
$\mathrm{C} \quad:$ 原子数比 $(=\mathrm{H} / \mathrm{M})$
$D_{\mathrm{j}, 12,}, D_{\mathrm{j}, 21}:$ 式 $(5)$ の係数
$E_{\mathrm{j}, \mathrm{n}} \quad:$ 式 $(3)$ の係数
$G_{\mathrm{j}, 1} \quad:$ 式 $(4)$ の係数
$\mathrm{f}_{\mathrm{n}}(\mathrm{t}) \quad:$ 測定温度の近似関数
$q_{\mathrm{w}} \quad:$ 表面熱流束
$T_{\mathrm{w}} \quad:$ 表面温度
$t \quad:$ 時間
$t_{\mathrm{n}}{ }^{*}:$ 時間遅れ
$\Gamma(\mathrm{n}) \quad:$ ガンマ関数
$\lambda \quad:$ みかけの熱伝導率
$\quad$ 添え字


$\mathrm{n} \quad$ : 各試料の温度測定点 $(\mathrm{n}=1,2)$

$\mathrm{r}$ : 標準試料

\section{2. 測 定 原 理}

門出ら(1)は, 最近熱伝導の逆問題解(2)を利用した熱 物性の測定法を提案し, 順問題解を利用した従来の測 定法 $\left.{ }^{3} \sim 6\right)$ と比較して容易にかつ測定温度と同程度の 精度で温度伝導率の測定ができることを数值計算で示 し，更に金属の温度伝導率の測定することによってそ の有効性について検証した結果を報告した。しかし， 逆問題解(2)を利用するに当たって, 測定開始時刻の推 定方法(1)が複雑であるという点に多少難点があった. その難点が逆問題解析の改善(7)によって解消され，測 定開始時刻を任意に設定することが可能となった。言 い換えると, 測定開始後, 十分な測定精度が得られる 温度変化であるなら, 任意の時間間隔で, 逆問題解を 利用して熱伝導率と温度伝導率を推定することが可能 となり, 測定開始時刻の制約がなくなり, 測定法がよ り容易になった。ここでは，その測定原理の概略を説 明する。

2.1 測定方法の考元方詳細な测定原理は文献(1) に述べられているので, ここではその原理を簡単に説 明する. 本測定法は, 1 次元半無限固体の逆問題解(2) を利用して熱物性を推定しているので，固体内のある 1 点の温度測定から, 表面温度と表面熱流束を推定す ることができる，温度伝導率は，固体内の異なる 2 点 で測定された温度から推定された表面温度がある測定 時間 $\left[\mathrm{t}_{1}, \mathrm{t}_{2}\right]$ 全体にわたって一致するように決定される. すなわち, 次式を満足するように温度伝導率が決定さ れる.

$$
F(a)=\int_{t_{1}}^{t_{1}}\left(T_{w, 1}(t, a)-T_{w, 2}(t, a)\right)^{2} d t \rightarrow 0
$$

ここで, $\mathrm{T}_{\mathrm{w}, 1}, \mathrm{~T}_{\mathrm{w}, 2}$ は，2つの異なる測定点の温度変 化からそれぞれ推定された表面温度である。また，半 無限固体近似が成立する範囲, すなわち時刻 $\mathrm{t}_{2}$ で試 料の反対側の表面温度変化が測定試料の温度変化の $1 \%$ 以下とする必要がある. また, 式(1)で推定され る温度伝導率は, 測定精度とほぼ同程度であることが 報告(1)されている.

次に, 熱伝導率については, 表面を通過する熱流束 が与えられると，次式から直ちに決定される．

$$
\frac{\lambda}{\sqrt{a}}=\frac{\int_{t_{1}}^{d_{2}} q_{w, r}(t) d t}{\int_{t_{1}}^{t_{2}} q_{w, 1}(t) d t}
$$

ここで， $\mathrm{q}_{\mathrm{w}, \mathrm{r}}$ は，基準となる材料から推定された熱流 束で， $\mathrm{q}_{\mathrm{w}, 1}$ は，試料側から推定された熱流束である。

熱伝導率の測定では, 基準となる試料が必ず必要と なる，その理由は，温度と熱が互いに独立な物理量で あるため, 熱量単位を含む熱伝導率を温度測定のみで は決定できないという事情による，従って，熱量（熱 流束）の測定については, 既知の熱伝導率を持つ材料 を基準材料として使用し, 有限平板に対する逆問題解 (2)を利用することによって $\mathrm{q}_{\mathrm{w}, \mathrm{r}}$ を推定する必要がある. なお有限平板に対する逆問題解は, 固体内に 2 点の測 定点が必要となる.

熱伝導率の推定精度は, 温度伝導率の推定と比較す ると熱量の推定が必要となることからその精度は少な くとも 2 倍程度劣化する.

2.2 表面温度と熱流束の推定法 1 次元非定常熱 伝導の逆問題解(2)から表面温度と表面熱流束は半無限 固体については式(3)と式(4)で, また有限固体につい ては，その表面熱流束は式(5)で与えられる.

「表面温度」

$$
\frac{T_{w, n}}{T_{0}}=\sum_{j=-1}^{N} E_{j, n}\left(t-t_{n}^{*}\right)^{\frac{j}{2}} / \Gamma\left(\frac{j}{2}+1\right)
$$

「表面熱流束」

$$
\begin{aligned}
q_{w, 1}(t) & =\frac{\lambda}{\sqrt{a}} \sum_{j=-1}^{N} G_{j, 1}\left(t-t_{1} \cdot\right)^{\frac{j}{2}} / \Gamma\left(\frac{j}{2}+1\right) \\
q_{w, r}(t) & =\frac{\lambda_{r}}{\sqrt{a_{r}}}\left\{\sum_{j=-1}^{N} D_{j, 12}\left(t-t_{1}^{*}\right)^{j / 2} / \Gamma\left(\frac{j}{2}+1\right)\right. \\
& \left.-\sum_{j=-1}^{N} D_{j, 21}\left(t-t_{2}^{*}\right)^{j / 2} / \Gamma\left(\frac{j}{2}+1\right)\right\}
\end{aligned}
$$

式(3)，(4)や(5)の係数 $E_{\mathrm{j}, \mathrm{n}}, G_{\mathrm{j}, 1} ， D_{\mathrm{j}, 12}$ や $D_{\mathrm{j}, 21}$ に ついては, 文献(2)に詳細に説明されている。なお, 逆 問題解は，表面にできるだけ近い情報（温度）を用い た方が原理的により正確な推定となることから熱流束 の推定には表面により近い測定温度 $(\mathrm{n}=1)$ を利用し ている. また, $\lambda_{\mathrm{r}}$ と $a_{\mathrm{r}}$ は, 基準材料の熱伝導率と温 度伝導率である。

2.3 測定温度の近似 ある測定点での温度変化は, 時間のみの関数となることから, 前報(1) と同様に次式 の関数形を使用する。

$$
f_{n}(t)=\sum_{k=0}^{N} \frac{b_{k, n}}{\Gamma(k / 2+1)}\left\{t-\left(t_{10}+t_{n}{ }^{*}\right)\right\}^{\frac{k}{2}}
$$

なお, 測定温度の時間間隔は $\left[\mathrm{t}_{10}, \mathrm{t}_{20}\right] て ゙$, 時刻 $\mathrm{t}_{10}, \mathrm{t}_{20}$ は，それぞれ $\mathrm{t}_{10}=\mathrm{t}_{1}-\mathrm{t}_{0}, \mathrm{t}_{20}=\mathrm{t}_{2}+\mathrm{t}_{0}$ で, 時間 $\mathrm{t}_{0}$ は, 時間間隔 $\left[t_{1}, t_{2}\right]$ の $5 \%$ 程度, すなわち $t_{0}=0.05\left(t_{2}-t_{1}\right)$ とすれば十分である. 測定時間を検定時間 $\left[t_{1}, t_{2}\right]$ より 時間 $\mathrm{t}_{0}$ だけ広く設定した理由は, 逆問題解の精度が 
両時刻端近くで劣化(2)するためである．前報(1,2) から 項数 $\mathrm{N}$ についても， $\mathrm{N}=5$ 程度で十分高い精度となる ことが報告されていることから，本測定でも $\mathrm{N}=5$ を 採用した。

式(6)の係数 $b_{\mathrm{j}, \mathrm{n}}$ は, 測定温度を $\mathrm{N}=5$ で最小自乗 近似することによって決定される。

\section{4 測定時間の設定とサンプリング点数 逆問題} 解（式(3)，(4)，(5)) は, ある時間 $\left[\mathrm{t}_{1}, \mathrm{t}_{2}\right]$ で生じた温 度変化を式(6)で精度良く近似できれば，その時間内 の表面温度と熱流束を近似式とほぼ同等な精度で推定 できることが報告(7)されている，従って，測定原理か ら推定された熱物性值は, 式(3)〜 (5)で推定された表 面温度と熱流束の精度に大きく依存することになる。 言い換えれば，精度の良い近似式(6)が得られるよう に測定時間 $\left[\mathrm{t}_{1}, \mathrm{t}_{2}\right]$ を任意に設定すれば良いことにな る. 従って, 測定開始時刻は測定点で検知された温度 が十分な測定精度 $(0.1 \sim 1.0 \%)$ となる時刻とすればよ く, 測定終了時刻は, 半無限固体近似が適用できる範 囲内で設定すればよい。一方，設定時間内の測定温度 のサンプリング数は 20 点以上となるように選定すれ ば十分であることが報告(1)されている。

なお，ここで述べられた時間の設定方法を行っても， 推定精度に問題がなかったことが，数值実験と既知の 金属材料を用いた実験で確認されている。

\section{3. 実験装置と実験方法}

3.1 実験装置図 1 は, 本実験装置の全体図を示 す。また，図 2 は試料である水素吸蔵合金と水素を封 入するための容器で, 実験装置主要部を示す.

この容器（直径 $50 \mathrm{~mm}$, 高さ $60 \mathrm{~mm}$ ）内の水素吸 蔵合金は，数十ミクロン程度の粒子状となっており， 水素の吸蔵状態によって原子数比が変化すると同時に 粒子間に水素が存在しているという状態となっている ので，ここでの測定は，水素吸蔵合金の見かけの温度 伝導率と見かけの熱伝導率の同時測定となっている。 水素吸蔵合金は，水素を吸蔵することによってその体 積が增大し，吸収終了時では，その体積が約 2 倍近く まで膨張する。この膨張を考虑して，水素吸蔵合金の 初期充填量は容器内容積の半分程度である。

測定は, 圧力, 原子数比および温度を所定の条件に 設定後, 試料を非定常加熱するという方法で行われて いる，測定中は，図 1 に示されるように初期設定温度 と同じ温度の恒温浴槽内に装置全体を取り付け, 周囲 への熱損失を極力小さくできるようにしている.

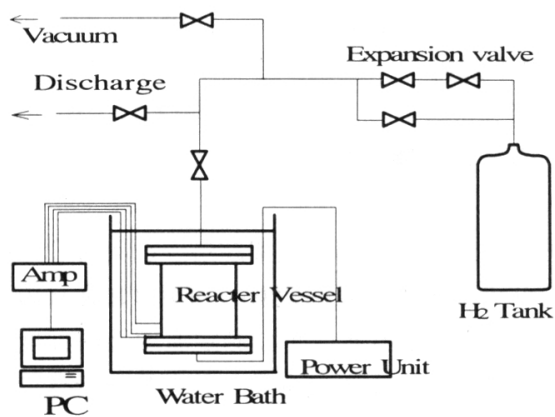

Fig. 1 Schematic diagram of whole experimental apparatus

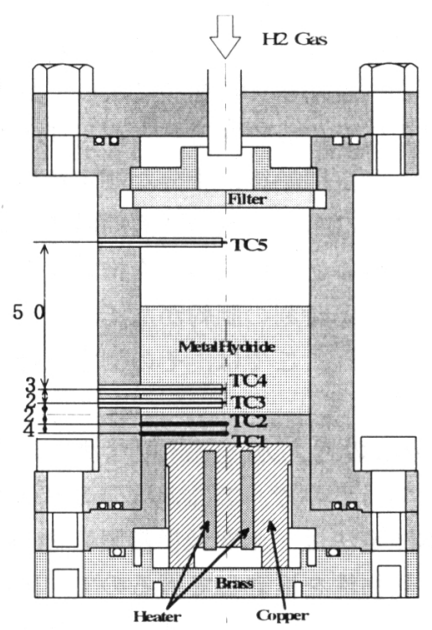

Fig.2 Main part of experimental apparatus

水素吸蔵合金の見かけの熱伝導率と温度伝導率は, 圧力 $\mathrm{p}=0.1 \sim 1.0 \mathrm{MPa}$ の範囲では一般に $1 \mathrm{~W} /(\mathrm{mK})$ と $10^{-6} \mathrm{~m}^{2} / \mathrm{s}$ 程度であることが報告(8 11)されており,金 属と比較してかなり小さい值である，従って，合金の 温度上昇を $10^{\circ} \mathrm{C}$ 程度に押さえ，かつ大きい温度分 布を避けるためには, 供給熱量 $\left(10^{4} \mathrm{~W} / \mathrm{m}^{2}\right.$ 程度の熱 流束)を小さく(緩やかな加熱に) する必要がある。

一方, 基準材料については, 出来る限り 1 次元の熱 流れを得るためには, 熱伝導率が大きくかつ薄い円盤 状の材料であることが望ましい。しかし，熱伝導率が 大きくかつ薄い円盤形状を使用すると小さい熱流束で は十分な温度差（熱電対の精度を考虑すると $2{ }^{\circ} \mathrm{C}$ 以 上）が取机なくなり，熱流束の推定精度が劣化するこ とから, 基準材料としてステンレス鋼（直径 $50 \mathrm{~mm}$, 厚さ $10 \mathrm{~mm}$ ）を使用することにした。ステンレス鋼 と容器との間には, $0.2 \mathrm{~mm}$ 程度の隙間を設定し, か 
つ円筒部と円盤部の接続部には狭い溝を設定すること によって，半径方向の熱流れを少なくする工夫が施さ れている.

熱の供給は，銅ブロックに埋め込まれた加熱用ヒ一 ターによって行われている. 銅ブロック(直径 40 $\mathrm{mm}$, 厚さ $40 \mathrm{~mm}$ ) は, ステンレス鋼と比較して 20 倍以上大きい熱伝導率を持っていること, および小さ い熱流束となっていることから，ほぼ均一温度(鉆直 方向の温度勾配 $0.03 \sim 0.04{ }^{\circ} \mathrm{C} / \mathrm{mm}$ ) で上昇していると 見なせる.さらに，ステンレス鋼の円柱部の半径は， 軸方向の厚さと比較して十分な大きさ（5 倍）で, 熱 流れが 1 次元近似できるように設計されている. なお, 本実験範囲内での熱の流れは, 熱入力開始後 120 秒 以内であれば，中心部分（熱電対が設定された部分） では 1 次元熱流れとなっていることが数值計算（加熱 部のみからの熱入力という境界条件設定）によって確 認されたことを記しておく．測定実験での合金への熱 入力は, 胴ブロックの熱容量のため加熱開始後約 30 秒後となっている（図 4 参照）.

温度は, ステンレス鋼内で 2 点 $(\mathrm{TC} 1,2)$, および水 素吸蔵合金内の 3 点(TC3，4，5）で測定されている.

TC5 の測定点は, 平衡状態を確認するために使用し た. 熱電対 TC1 と TC 2 の位置は, 図 2 に示される ように基準表面から $2 \mathrm{~mm}$ と $6 \mathrm{~mm}$ で, また TC 3 と TC 4 の位置は, 基準表面から水素吸蔵合金側に 2 $\mathrm{mm}$ と $5 \mathrm{~mm}$ となっている.

熱電対 $\mathrm{TC} 1,2,3,4$ での非定常温度測定は, 増幅器 と $\mathrm{AD}$ 変換器を通して $\mathrm{PC}$ コンピュータで自動計測さ れている.そのサンプリング周波数は, $50 \mathrm{~Hz}$ で,

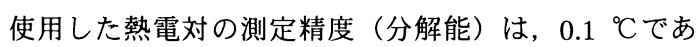
る.なお, 本実験でのサンプリング周期は, $1 \mathrm{~Hz}$ 程 度でも十分である. ステンレス構内の熱電対の位置は, 前実験終了後, 熱電対部分を開切削して, 精密測定し た結果を用いて計算しているが，MH 内の位置につ いては, $0.1 \mathrm{~mm}$ 程度の範囲内で設定されている.こ の誤差に伴う推定值の誤差は，5\%程度(1)となる.

3.2 测定方法测定容器内を初めに 1 時間程度真 空引き（真空度, 約 $7 \mathrm{~Pa}$ まで）する. その後, 全て のバルブが閉まっていることを確認する. 水素ボンベ から水素を所定の圧力になるまで供給する. 同時に, 恒温層の温度を所定の温度に維持し, 熱平衡状態での 温度と圧力から $\mathrm{MH}$ の水素原子数比 $\mathrm{C}[\mathrm{H} / \mathrm{M}]$ （MH 1 モル中に含まれる水素原子数の割合）を求めた。その 後, ヒーターによる加熱を開始し，合金層内の温度お よびステンレス鋼（熱伝導部）の温度変化を非定常測
定する. 一連の測定は, 同一設定温度で, 水素原子数 比を変化させるという手順で行われている.

\section{3 水素吸蔵合金の特性本実験で使用した試料} は, $\mathrm{AB}_{5}$ 合金と呼ばれるもので, 水素吸蔵時の水素原 子数比は, 図 3 に示される試料 $\mathrm{AB}_{5}$ の相平衡（P-TC）線図 ${ }^{(12)}$ を用いて求めた. 一般に, 水素吸蔵合金は, 図 3 中の B - C 区間の原子数比域（プラト一域とい う）で使用される. 非定常測定のために必要な温度変 化は, 本測定法では $10{ }^{\circ} \mathrm{C}$ 程度必要である。この温度 上昇に伴う圧力の上昇は, 約 $0.02 \mathrm{MPa}$ であったこと を記しておく.

いろいろな組成の合金が $1 \mathrm{~mol}$ あたりの水素吸蔵量 を増加させるために開発されているが, $\mathrm{AB}_{5}$ 合金もそ の一つである．著者らの調査範囲では, $\mathrm{AB}_{5}$ 合金のみ かけの熱伝導率や温度伝導率を測定したデータは見あ たらなかったので, 他の水素吸蔵合金 ${ }^{8}$ －11)の特性を 本実験範囲と関連づけて参考までに記すと, たとえば, $\mathrm{LaNi}_{4.7} \mathrm{Al}_{0.3}$ や $\mathrm{Ti}_{0.98} \mathrm{Zr}_{0.02} \mathrm{~V}_{0.43} \mathrm{Fe}_{0.09} \mathrm{Cr}_{0.05} \mathrm{Mn}_{1.5}$ 合金につ いては, Hahne and Kallweit ${ }^{(8)}$ によって詳細な測定が みかけの熱伝導率について行われている. それによる と, 温度一定のときの熱伝導率はいずれの合金に対し ても水素の原子数比が増加すると増大することおよび 系圧の増加に対しても増大することが報告されている. また, $\mathrm{LaNi}_{4.7} \mathrm{Al}_{0.3}$ および $\mathrm{Ti}_{0.98} \mathrm{Zr}_{0.02} \mathrm{~V}_{0.43} \mathrm{Fe}_{0.09} \mathrm{Cr}_{0.05}$ $\mathrm{Mn}_{1.5}$ 合金に対するみかけの熱伝導率の值は, 温度 $20{ }^{\circ} \mathrm{C}$ のプラトー域で $0.3 \sim 0.5 \mathrm{~W} /(\mathrm{mK}), 0.9 \sim 1.3$

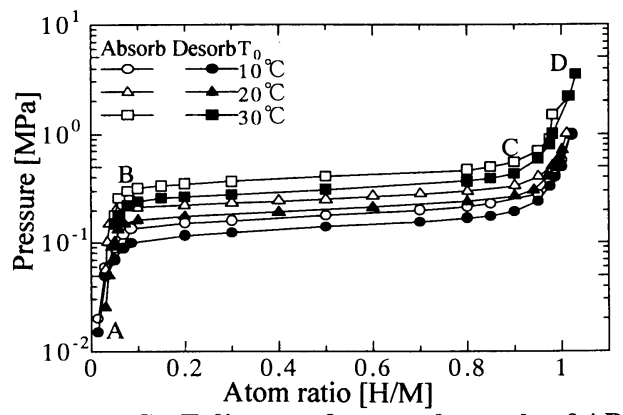

Fig.3 P - C - T diagram for tested sample of $\mathrm{AB}_{5}$

Table 1 Experimental range

\begin{tabular}{|l|c|}
\hline $\begin{array}{l}\text { Test sample } \\
\left(\mathrm{AB}_{5}\right)\end{array}$ & $\mathrm{La}_{0.57} \mathrm{Ce}_{0.03} \mathrm{Pr}_{0.09} \mathrm{Nd}_{0.3} \mathrm{Ni}_{4.87} \mathrm{Mn}_{0.11}$ \\
\hline $\begin{array}{l}\text { Initial } \\
\text { temperature }{ }^{\circ} \mathrm{C}\end{array}$ & \multicolumn{1}{|c|}{$10,20,30$} \\
\hline Atom ratio $\mathrm{H} / \mathrm{M}$ & $0.1,0.3,0.5,0.7,0.9$ \\
\hline & $10{ }^{\circ} \mathrm{C}: 0.148 \sim 0.219$ \\
Pressure $\mathrm{MPa}$ & $20{ }^{\circ} \mathrm{C}: 0.227 \sim 0.336$ \\
& $30^{\circ} \mathrm{C}: 0.338 \sim 0.502$ \\
\hline
\end{tabular}


となっている. Ishido ら ${ }^{(9)} は, \mathrm{Mg}$ 系合金のみかけの 熱伝導率を測定し, その值が水素の原子数比の増加に つれて增大することおよび系圧とともに增大すること を報告している，そして，この值は，測定範囲内で, $\mathrm{MgNi}$ 系では〜 $3.48 \mathrm{~W} /(\mathrm{mK}), \mathrm{Mg}_{2} \mathrm{Ni}$ 系では〜 1.16 $\mathrm{W} /(\mathrm{mK})$ まで増加している。

\section{4 実験範囲本実験で測定された熱物性は, 試} 料（ $\mathrm{AB}_{5} ）$ の見かけ熱伝導率と温度伝導率で表 1 に示 される範囲で測定が行われた. 原子数比の範囲として $\mathrm{C}=0.1 \sim 0.9 \mathrm{H} / \mathrm{M}$ を選定した理由は, 図 3 に示される ように P-C-T 線図上でプラト一域に対応する領域で, かつ実際に使用される領域であることからである.

3.5 水素吸蔵合金の性質 1 章で述べたように $\mathrm{AB}_{5}$ 系水素吸蔵合金は, 数十ミクロン程度の粒子で液 体の状態で水素を吸藏している．また，粒子は多孔質 状となっていることから水素気体も共存した状態とな っている．原子数比を一定に保って加熱すると合金の 温度が上昇するため, 系内の圧力は図 3 に示されるよ うに上昇することになるので，水素気体が多少圧縮さ れることになる. しかし，原子数比は変化していない ので，水素化反応による反応熱の発生は生じない， なお, 合金自身の熱伝導率は, 約 $8 \mathrm{~W} /(\mathrm{mK})$ で, 水 素気体の熱伝導率と温度伝導率は, $1 \mathrm{~atm}, 27^{\circ} \mathrm{C}$ で $0.181 \mathrm{~W} /(\mathrm{mK}), 1.55 \times 10^{-4} \mathrm{~m}^{2} / \mathrm{s}$ である.

\section{4. 測 定 結 果}

図 4 は, 原子数比 $\mathrm{H} / \mathrm{M}=0.3,0.7$ で, 本測定で得 られた固体内の温度変化の一例を示す. 図 2 に示され る 4 つの測定点（TC1～4）での温度変化から, 逆問 題解を利用して, 温度伝導率と熱伝導率を推定するこ とになる。

\section{1 熱物性の計算手順}

1. 温度変化が十分な測定精度となった時刻を適当 に選定する，例えば，図 4 の例では， $\mathrm{t}_{10}=30 \mathrm{sec}$ で温度変化が検知されている。

2. 終了時刻 $\mathrm{t}_{2}$ も, $10^{\circ} \mathrm{C}$ 程度の温度変化があれば十 分であることおよび 1 次元半無限固体近似の制約 から, 図 4 の例では, $\mathrm{t}_{20}=\mathrm{t}_{2}+\mathrm{t}_{0}=160 \mathrm{sec}$ とした (180 sec まで半無限固体近似ができる)

3. 時間 $\left[\mathrm{t}_{10}, \mathrm{t}_{20}\right]$ での温度変化を式(6)で最小自乗近似 し，係数 $b_{\mathrm{j} . \mathrm{n}}$ を定める.

4. 各式の係数を計算する.

5. 式(1), (2)から, 温度伝導率と熱伝導率を計算す る.
なお，測定時間の選定は，測定精度と加熱の強さす なわち温度変化のレベルに大きく依存することにな るから, 加熱の強さを熱伝導率の大きさと温度変化 に対して適切に設定する必要がある。 また測定時間 については, $\mathrm{t}_{20} \leq 180 \mathrm{sec}$ の範囲内で, $\mathrm{t}_{20}=140,160$ と $180 \mathrm{sec}$ の場合について測定結果を検討した結果, 測定值は数\%の測定誤差範囲内一致することが確認 された.

図 4 に示される温度変化を用いて, 推定された熱物 性值を圧力や原子数比で整理した結果を図 5 〜図 8 に 示す. 図中の Run No. は繰り返し測定を実施したとき の測定結果を示す.

4.2 繰り返し回数の影䈏 同じ設定条件に対して, 水素の吸藏と放出を数回繰り返しながら，同じ測定を 行った. 図中には, 試行繰り返し回数とその時の測定 值が示されている.

図 5〜図8 から, 温度伝導率の值は試行繰り返し 回数に殆ど依存していないことがわかるが, 熱伝導 率については, $\mathrm{C}=0.9 \mathrm{H} / \mathrm{M}$ を除いて試行回数の増加 につれて多少増加する傾向が見られる。これは, 試 行回数の增加につれて, 合金粒子が微細化するため

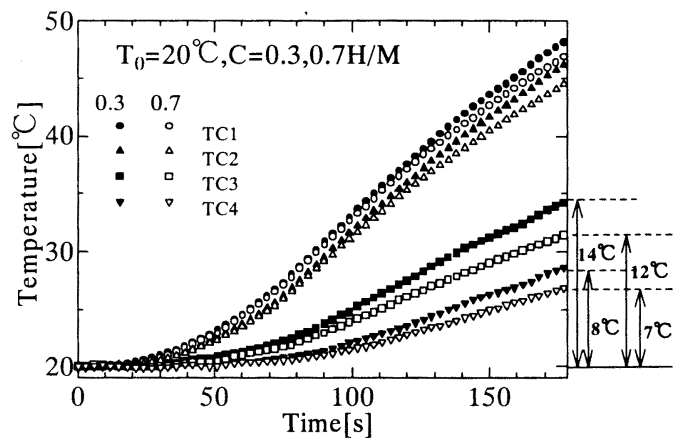

Fig. 4 Temperature change at a measuring position during heating (TC1 -TC4: Position of thermocouples)

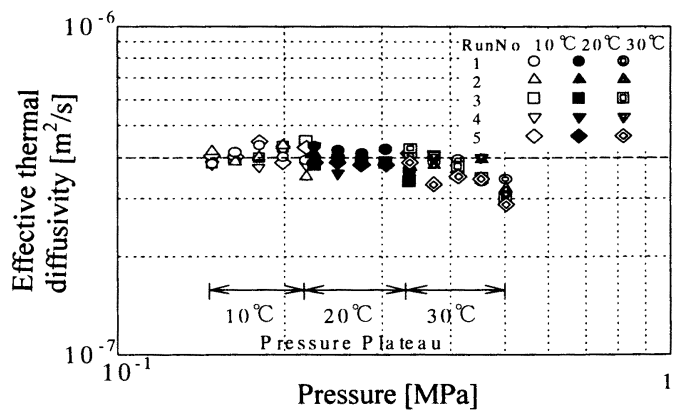

Fig. 5 Effective thermal diffusivity vs. pressure 


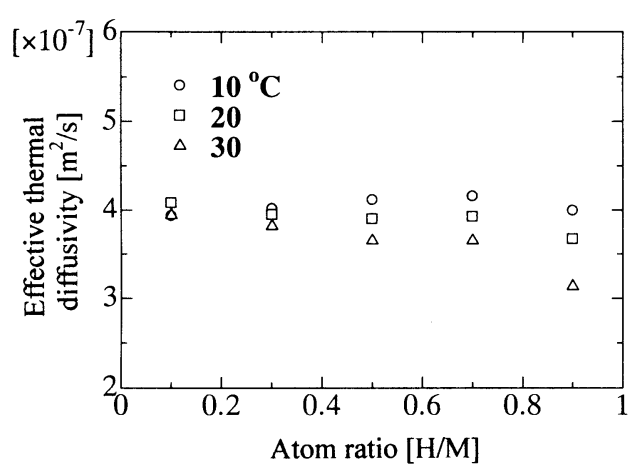

Fig. 6 Effective thermal diffusivity vs. atom ratio

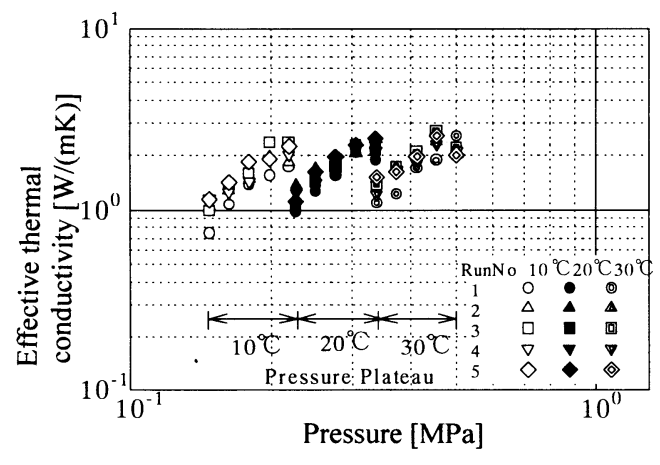

Fig.7 Effective thermal conductivity vs. pressure

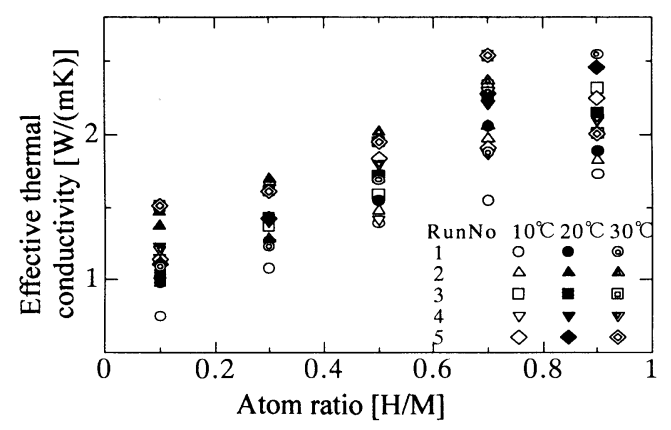

Fig.8 Effective thermal diffusivity vs. atom ratio

に見かけの密度が増加するためと推定している．ま た, 測定結果が試行回数によって多少異なっている のは, 測定誤差によるものかあるいは多孔質の構造 の変化によるものか不明である。

4.3 見かけの温度伝導率の推定值 図 5 から, 温度 伝導率の值は, 温度 $10^{\circ} \mathrm{C}$ では, 圧力の変化に対しても
ほぼ $a=4 \times 10^{-7} \mathrm{~m}^{2} / \mathrm{s}$ の大きさとなっている. したが って, 温度 $10^{\circ} \mathrm{C}$ では水素の原子数比が变化しても温度 伝導率の值はほぼ一定であることが分かる. 一方, 温 度 $30^{\circ} \mathrm{C}$ では, 圧力の増加につれて温度伝導率の值は減 少する傾向が見られる. 図 5 を参考にしながら換言す ると, 水素の原子数比が高くなると温度伝導率の值は 滅少することになる.

図 6 から, 見かけの温度伝導率は, 合金温度 $10^{\circ} \mathrm{C} て ゙$ は, 原子数比の変化に対してほぼ一定となっているが, $30^{\circ} \mathrm{C}$ では, 原子数比の増加につれて小さくなる傾向が 見られ, 特に C = $0.9 \mathrm{H} / \mathrm{M}$ では, $30 \%$ 程度減している. 一般傾向として, 合金の温度が高くなると原子数比の 増加につれて減少する傾向が見られる．これらの減少 理由については, 不明である.

4.4 見かけの熱伝導率の推定值 図 7 から, 熱伝 導率は, 温度一定のとき, 圧力とともに熱伝導率がほ ぼ直線的に増加していることが分かる. また, 図 8 か ら, 熱伝導率は, 温度一定のとき原子数比の上昇につ れてほぼ直線的に増加していることが分かる.これは, $\mathrm{P}-\mathrm{C}-\mathrm{T}$ 線図から容易に推定できるように, 圧力の 増加につれて原子数比が直線的に高くなっているため である. そして, 原子数比が大きくなるにつれて熱伝 導率が大きくなっているのは, 水素の充填量が増加す ることによって, MH 内に吸蔵された液状水素の増加 による熱伝導効果が現れたのではないかと推察してい る.

図 7,8 に示される $\mathrm{AB}_{5}$ の熱伝導率の原子数比や圧 力に対する特性は, $\mathrm{AB}_{5}$ 以外の水素吸蔵合金の熱伝 導率 $(8,9)$ とほぼ同様な特性であることが分かった。

\section{5. とめ}

水素吸蔵合金 $\left(\mathrm{AB}_{5}\right)$ の見かけの温度伝導率と見か けの熱伝導率を同時に測定する装置を製作し，それぞ れの值を測定し, 以下の結果を得た.

1. 見かけの温度伝導率の值は, 温度範囲 $10 \sim 30{ }^{\circ} \mathrm{C}$ で平均的には $4 \times 10^{-7} \mathrm{~m}^{2} / \mathrm{s}$ であるが, 原子数の 増加につれて上昇する傾向, および圧力の上昇 に伴って多少減少する傾向がある.

2. 見かけの熱伝導率の值は, 温度範囲 $10 \sim 30{ }^{\circ} \mathrm{C}$ で 1 3 W/(mK)の大きさで, 圧力の増加につれてほ ぼ直線的に増加する傾向がある.

3. 見かけの熱伝導率は, 圧力の上昇につれて大き くなる。 
おわりに, 本研究は, 経済産業省, 新エネルギー・ 産業技術総合開発機構の水素利用国際クリーンエネル ギーシステム技術（WE-N E T ）第Ｉ期研究開発プ ロジェクトの一環として行われたもので, ここに記し て関係各位に感謝する. また, 本実験に積極的な協力 を頂いた当時の大学院生中村好典君と原本千弘君に感 謝する。

\section{文献}

（1）門出政則, 光武雄一, 横山弘典, 機論, 66-649B, (2000) 2449-2456.

（2）門出政則, 光武雄一, 志岐隆浩, 西本友哉, 機論, 66642B, (2000), 519-527.

（3）小林清志, 日本機械学会誌, 77-668, (1974), 754-761

（4）小林清志, 日本機械学会誌, 81-714, (1978), 452-457.

（5）姫野修廣, 日向滋, 梁取美智雄, 機論, 58-545B, (1992),187-192.
（6）山田悦郎, 谷口博, 浜出信正, 真鍋幸弘, 機論, 56-521B, (1990), 155-160

（7）門出政則, 劉維, 有馬博史, 光武雄一, Hammad, J., 機論, 68-671B, (2002), 2093-2097.

(8) Hahne, E. and Kallweit, J., Int. J. Hydrogen Energy, 23 2, (1998), $107-114$.

(9) Ishido, Y., Kawamura, M. and Ono, S., Int. J. Hydrogen Energy, 7 -2, (1982), $173-182$.

(10) Pons, M. and Dantzer, P., J. of the Less-Common Metals, 172 - 174, (1991), 1147 - 1156.

(11) Nagel, M., Komazaki, Y and Suda, S., J. of the LessCommon Metals, 120, (1986), $35-43$.

(12) 私信（日本重化学工業より PCT データ) 